\title{
Urban Economic Development and Multinational Corporations in Western City of China under Globalization
}

\author{
Yingyi Cao ${ }^{1, a^{*}}$ and Haiying Ma ${ }^{2, b}$ \\ ${ }^{1,2}$ School of Economics, Northwest University for Nationalities, Lanzhou (730124), P.R.China \\ a79059732@qq.com, ${ }^{\mathrm{b}}$ Ixmahaiying8888@163.com
}

Keywords: Globalization; Multinational corporations, Agglomeration effect; Technology spillover

\begin{abstract}
The analysis of the relationship between urban economic development and multinational corporations in western China shows that: investment for multinational corporations in western region is dominated by southwest cities, that cities in Guangxi take up the highest proportion, whereas amounts for foreign direct investment in Chongqing and Chengdu take up the largest parts. On the whole, investment itself have feature of agglomeration, cities where multinational corporations have a high emphasis on foreign direct investment and its speed of economic growth is relatively higher than that of multinational corporations with low emphasis on foreign direct investment.
\end{abstract}

\section{Introduction}

Globalization is the direction and trend for world economic development. And multinational corporations are the main driving force to the accelerated development of globalization. To understand globalization what a positive or negative relationship between economic development of western China and investment for multinational corporation exists. The theory for foreign direct investment of multinational corporations and urban economy relationship: The Eclectic Paradigm of International Production hold that emergence of corporate foreign direct investment will be based on advantage factors combination of three aspects, including that multinational corporations have ownership advantage which the host enterprises do not have, internalization advantages, and geographical advantages explaining incentives and conditions of foreign direct investment for multinational corporations. Some scholars believe foreign direct investment of multinational corporations, especially cooperative holding enterprises can greatly reduce the communication, negotiation, employment and other transaction costs, and help accelerate the pace of international investment in multinational corporations. In the era of globalization, McCann P and ACS Z.J explored importance of urban economies of scale, multinational corporations became the key to linking cities with the world, and urban economy continued to promote national economic development.

Domestic scholars and experts mainly utilize qualitative analysis for study, in the literature on the relationship between urban economic development and multinational corporations. Such Wang Hao believes regional headquarters of multinational corporations for operations and agglomeration that have an obvious role for promotion of local urban economic development. Meanwhile, government enterprises of host country with a series of cooperation and support interaction can make relations between multinational corporations and local economy more and more closely. Li Jian believes that the trend of cluster distribution for multinational corporations is significant, and the agglomeration effect is produced at the same time and also generates cluster effect. Guo Yanling deems that capital investment has a significant role in promoting economic growth, domestic investment has a dominant place, and multinational foreign direct investment in economic growth is also very obvious, with added explanation from technology spillover effect and human capital effect of two aspects. Li Xin believes that the restrictions on multinational companies in China R \& D investment technology spillover have two reasons: their own technology protection policy multinational corporations are restricted, and some of city in China lacking of conditions cannot absorb technology spillover. Yu Zhengke deems that regional headquarters of multinational Corporations should have selective, 
targeted, initiative features for attracting them to come to China, and government should pay attention to change function and construction for hard and soft environment, to maximize multinational headquarters effect. Jing Zhongfan, taking examples of China and Korea relationship, analyzes the characteristics of multinational network structure for Chinese city, basic elements distribution of network presents the location tendency while expanding of multinational urban network. Gu Chaolin focuses on three types of strategic positions in export processing zones, offshore banking centers and global cities, that have become economic globalization, productive services and multinational corporations development, and the formation of international financial and business centers have become the new urban economy phenomenon. Wang Zhenzhong propose multinational corporations are urbanization boosters, and the basic unit for international competition locates in city as urbanization calling for new thinking.

\section{Features on City Distribution in Western and Investment of Multinational Corporations}

Relationship Between Multinational Corporations and Foreign Direct Investment. Broadly speaking, multinational companies are overseas companies with direct investment. In practice, the main body of foreign direct investment for those firms who have considerable performance in their own country, and turn to overseas investment for achieving production and business activities as the goal of the enterprise for internationalization and globalization, that is foreign direct investment. Making clear relationship between multinational corporations and foreign direct investment becomes necessary, as the main part for foreign direct investment including enterprise and natural person. And the main provider for foreign direct investment is multinational corporations. It is believed that multinational corporations almost cover all foreign direct investment-direct investment for global top 500 enterprises in overseas reach more than $80 \%$ of global foreign direct investment, and large world multinational companies become the dominant force in foreign direct investment behavior. That make the main provider for foreign direct investment of multinational corporations. Wherein the most significant form for global strategy of multinational corporations is foreign direct investment. Since multinational corporation with globalization trend, average growth rate on foreign direct investment was $18.47 \%$ during 2001- 2014, while the average growth rate of domestic output was $9.82 \%$. Proved that the average growth rate was almost 2 times of domestic output. Foreign direct investment turns into the dominant force for promoting international economic and trade activity, being main forms for global strategy of multinational corporations.

Features on Multinational Corporations Distribution of Western City. Multinational corporations with joint or sole methods enter into China. Because the exact data of multinational corporations are difficult to obtain, that based on the relationship between multinational corporations and foreign direct investment, the paper shows investment for multinational corporations in China from foreign direct investment which cumulative number ranking for part of western cities invested by foreign direct investment enterprises, and there are 9 western capital cities in Top 20, proved that foreign direct investment is mainly concentrated on capital city; investment mainly focus on the southwest region, like Sichuan, Inner Mongolia Autonomous Region, Guangxi Zhuang Autonomous Region, three provinces; foreign investment enterprises have large gap having uneven distribution, Chongqing ranks first more than 17 times compared with Lanzhou of 20th. Distribution for foreign direct investment enterprises in western China represents a decreasing trend from south to north, which is related to overall strength of city. Direct investment for multinational corporations tends to cities of strong economic capability as its strong absorptive capacity to foreign investment. Cities with higher total amount of GDP have more investment from foreign enterprises, illustrating that foreign direct of investment multinational corporations value the overall economy. There are 5 cities in Guangxi Zhuang Autonomous Region invested by foreign investment enterprises, like Nanning, Guilin, Liuzhou, Wuzhou, Beihai with a high proportion of each western province, autonomous regions and municipalities, among top 20 of foreign direct investment cities. As China-ASEAN Free 
Trade Zone is located in Nanning of Guangxi where has higher degree for opening, and relatively contacts with each country of ASEAN, with nearest advantage.

Features on Multinational Corporations Investment in Western City. The most important form of multinational corporations based on global strategy is foreign direct investment, and newly incremental contract number of accumulative number each year represent investment in western city from foreign direct investment of mutational corporations, the number of contacts items have unbalanced distribution and large differences, investment contract items mainly sign in southwest city among top 20 cities, which there are 6 cities among top 20 cities from Guangxi with high popularity, including: Nanning, Wuzhou, Guilin, Qinzhou, Liuzhou, Beihai. But seeing from city number, Chongqing and Chengdu are the excellent signing for foreign direct investment. Western region have potential to be explored and southwest region should increase investment for absorbing investment and development from multinational corporations strongly. Investment features and distribution keep same in western city of China, part of city investment becomes investment emphasis spreading for surrounding city gradually, and south with a higher number than north region.

\section{Western Economic Development and Multinational Corporations}

Multinational corporations have a strategic choice for city investment, with different strategies for different regions, and any corresponding effects will be worked.

Agglomeration Effect Analysis. Agglomeration effect is characterized by a variety of industries and economic activities that focus on a certain space to produce a certain economic effect and to attract economic activity for being closing each other, that leads to city formation and continuous expansion of such a phenomenon. Picking the proportion between value of industrial output from foreign direct investment enterprises of western city and value of industrial output among 2003-2013, influence of multinational corporations on urban industry in western China is discussed. City with high proportion where can be seen agglomeration effect caused western investment from multinational corporations,

There are features on large difference and unbalanced distribution. On the whole, foreign direct investment enterprises for each city of Guangxi have the strongest influence of industry city; shows a decreasing influence trends from southeast to northwest of each western city. Generally speaking, foreign direct investment enterprises influence for each capital city strengthen gradually during 2003-2013 being less than non-capital city of decreasing scope, the influence of top 20 capital cities represents declining tendency. The influence on non - capital cities industry of foreign direct investment has become remarkable. From the time perspective, foreign investment for multinational corporations are mainly from each city of Guangxi with gradual increase investment and expand from Guangxi to Sichuan, Chongqing, Shanxi, Inner Mongolia provinces, autonomous regions and municipalities.

Since 2000, direct investment of multinational corporations increase gradually and with a accumulation phenomenon, focused on Chongqing, Chengdu, Xi'an, that part of region are gathering large and medium cities, like Guangxi, Sichuan. Accumulation of foreign direct investment by multinational corporations benefits foreign capital introduction, which leads to entry of potential, related and other investors; benefits advanced technology of learning and using filling technological gaps; benefits talent inflow and cultivation and further human-source development; and benefits enterprises scale extending, jobs increase and relieve employment pressure to promote urban development. Accumulation city where is from western city of China, its economic aggregate rank continue to move forward, and the surrounding cities are also subject to a certain investment influence for promotion of urban economy development. However, the rate of urban economic development with low emphasis on foreign direct investment is relatively lower than that of multinational corporations.

Agglomeration Effect Analysis. Multinational corporations of globalization tendency let enterprises be globalization with its internal advantages, and inevitably involve technology spillover during process of foreign direct investment. The ways in which technology spillovers from multinational 
corporations and the factors that limit technology spillovers. Multinational corporations have three different approaches for investment production technology spillover in western city of China. First, technical demonstration and market competition drive technical learning and innovation; second, flow of human capital in enterprises promote knowledge and technology dissemination; third, link among each enterprises contribute to technology spillover. As the late beginning for western city of China, most cities exist such features that improve weakness simultaneously and absorb vigorously foreign investment for improving overall economic pace seizing the opportunity.

Technology spillover function of urban economic development: multinational corporations are a fresh source of power for urban economic development, which have negative and positive effects will be produced by technology spillover for investment economy. On positive views, technology spillover for mutational corporations have such following influences: increase of domestic R \& D fund, talent gathering and sharing talent, acceleration of technical spread and promotion of market competition, and production of scale effect. On negative views, spillover effects of foreign direct investment have a negative effect on the survival and development of local enterprises, including local brands in the competition out of market; loss of human resource of local enterprises 'anti-spillover' technology.

\section{Conclusion}

Investment in western city of China of multinational corporation mainly covers city in western, among which number of cities in Guangxi Autonomous Region is the highest; Chongqing and Chengdu are the largest feature amount for foreign investment. From overall perspective, investment has feature of agglomeration; cities with high emphasis on foreign direct investment of multinational corporation, its economy development speed is relatively higher than that of cities with low emphasis. But urban economic development benefits from direct investment of multinational corporations, attention should be paid to overcoming their own disadvantages and play their advantages to drive improvement and innovation for local production technology. Under globalization, multinational corporations spread all over of world and, and entry for foreign investment and enterprises accelerating urban economy to internationalization and globalization. Every country and region take various policies to absorb foreign investment and china is no exception. But urban economy development is not only depend on improvement of multinational corporations investment and also analyze in ration for western region investment, improvement and construction from external and internal part should be benefit to favorable conditions for urban economic development and environment.

Unbalanced situation of investment distribution, drive economic development in agglomeration region of multinational corporations, and enlarge unbalanced economy gap among cities. Economic globalization brought by globalization has accelerated investment pace of multinational corporations around the world, that is a great opportunity and challenge for western city in China while seizing opportunity and doing a lot of preparation to meet challenges. First, improving and perfecting market system and structure from aspects of government, enterprises, regulations, and environment for construction of clean, efficient and impartial government, which makes enterprises be main body for market economy to improve relevant regulations and perfect operation environment. Second, recognize the gap to locate accurately and strengthen independent innovation and awareness for intellectual property. Third, utilizing regional advantages build favorable economic environment for absorption of agglomeration to foreign investment. Improving infrastructure construction to strengthen links between enterprises and universities and improve quality for local labors. Forth, avoiding serious dependence on foreign investment that results in loss of independent innovation capacity, multinational corporations investment mainly employs local cheap labor costs, natural source and broad market and preferential policies, and much dependence on foreign companies should be avoided for loss of self-innovation ability during cooperation. 
Globalization brings investment for western city, and make increase of labor price level and fixed assets rents for eastern city of China, made some foreign enterprises of multinational corporation put their eyes on western city for industrial transfer and investment and realized the external environment for seizing opportunity to promote urban economic development. First, following national policy to improve urbanization level of western city. Cities where have large economic aggregate and high living standard for citizen have strong market demand and spending power. Improving urbanization to develop large and medium-sized cities and build favorable economic environment for absorption of investment and cooperation from multinational corporations. Second, strengthen cooperation and links among city and region to promote the occurrence of scale effect. Wherein links for city can strengthen cooperation and development among enterprises and also strengthen forward and backward linkage among enterprises, which investment, advanced technology, managerial knowledge and talent from multinational corporations enter into the region can be fully benefit from scale effect, capital and technology agglomeration effect.

Third, Western city around the region of 'one belt and one road' should follow that strategy to strengthen international trade and cooperation. Follow the trend of economic globalization, and employ region advantages of economic belt on Silk Road to strengthen international trade, improve level of foreign investment, enhance ability of cooperation with multinational companies. Forth, no blind pursuit of enterprises globalization and internationalizations, recognize international and domestic economic development situation, formulate effective and reasonable enterprise development plan, improve labor force quality for enterprise, enhance self-independent ability innovation, and promote development in agglomeration region for each other while promoting urban economic development.

\section{Acknowledgements}

This work is supported by Special Funds for Undergraduate Teaching Reform by Central University of Northwest Minzu University (Grant No:10019153), and by the Fundamental Research Funds for the Central Universities of Northwest Minzu University (Grant No. 31920170141).

\section{References}

[1] Zhao Chunming, Transnational corporation and international direct investment. Machine Industry Press(2009).

[2] Lu Xianxiang, New institutional economics, Wuhan: Wuhan University press(2013).

[3] Mccann, P., Acs, Z.J., Globalization:, Countries, Cities, and, Multinationals, Regional, Studies, 1(2011)17-32.

[4] Wang Hao, Study on the interaction between regional headquarters of multinational corporations and host cities . Shanghai: East China Normal University(2007).

[5] Li Jian, Location selection and regional economic development of regional headquarters of multinational corporations in China. Nanjing: Southeast University(2005).

[6] Guo Yanling, Study on the impact of transnational corporation investment on Sichuan's economic development. Chengdu: Sichuan University(2007).

[7] Li Xin, Technology Spillover Analysis of multinational corporations' R\&D investment in China, Taiyuan: Shanxi University of Finance and Economics(2008).

[8] Yu Zhengke, Development of multinational headquarters economy China strategy analysis, Shanghai: East China University of Science and Technology(2012). 